\title{
Elegy to Reinhart Buyno
}

\author{
Afonso Teixeira Filho
}

\section{Blank pages}

It was my desk that needed to be cleaned

I cannot find my papers... they were here

where are they?

There was dust on my desk

There will be forever

I cannot find my papers

I had to do that, but I will not anymore

I do not even know where my hands are

I cannot concentrate

I am at the point of losing my mind

Because I lost my papers

Which should be removed from my desk

I have cleaned my desk, my desk is clean

Clean of dust, clean of papers

Clean of my hands

It seems that my hands are dirty

It is impossible to write

Because I lost my papers and lost my mind

There was a blank page

It has gone

And will be forever 
Let me say goodbye at least

But I will not

Because forever is for never more

And I will never see more

Because my friend has gone and left a blank page on my desk

I could not concentrate since he left

Because he went away and will never come back

He left a blank page

Something must be written on this page

Many things must be written on this page

This page should show a poem about him

It cannot be that he has left a blank page

A blank page on the desk

He had so many things to say

We need to hear what he had to say

But what he had to say he will not say anymore

He left

He went away

He never will come back

And we will not hear

Everything we have is a blank page

I cannot concentrate

He has things to say

The papers on my desk

But he went away

Where are you? Could you tell me?

Where do you live now?

Do I know this place?

I should know. It is a better place, a commonplace 
Teixeira Filho, Afonso. Elegy to Reinhart Buyno.

I should say

You must tell me

Please, come back some day Some day I would find my place I would find my papers

I would find your place just to say farewell

But now I have to go, my friend I have to polish my shoes. 